\title{
European Union view on Personal Data in Intellectual Property Rights
}

\section{Dorin CIMIL ${ }^{*}$, Olesea PLOTNIC}

\begin{abstract}
The issue under investigation concerns whether personal data or personal information from the point of view of intellectual property constitutes as such a commodity or economic potential, which may be subject to alienation and registration as an object protected by the intellectual property system or represent a non-commercial object, without circulation in civil relations, with a special legal regime, connected to the fundamental human rights and freedoms. Recognition of personal data and other categories of information, related to the person (geolocation data, user-generated content) in terms of intellectual property rights as objects of civil rights, would allow the development of the data market, necessary for the functioning of innovative technologies on big data, cognitive calculations, the Internet of goods, and bringing these technologies into a legal and civilized field. The objective of the article is to appreciate whether personal data is subject to any intellectual property rights by the assessment of EU jurisprudence in line with national legal framework of the Republic of Moldova.
\end{abstract}

Keywords: personal data; personal information; intellectual property rights, fundamental human rights and freedoms; objects of civil rights; innovative technologies.

JEL COD: P 37(P 48), L 84

\section{Introduction}

For the effective functioning of the market, the participants of the civil circuit must have full and multifaceted information about the demand and

\footnotetext{
${ }^{*}$ PhD. Dorin CIMIL, President of Henri Capitant Association. Email: dorincimil@gmail.com

* PhabD Olesea PLOTNIC, General secretary of Henri Capitant Association. Email: plotnicolesea.aum@gmail.com
} 
supply of goods, works, and services, as well as other socio-economic legal factors that allow civil law subjects to make some decisions. At the same time, the oversaturation of the information market would lead to an economic problem, when people, having access to information at any time and at any time, without any limit would devalue its cost and deprive its owners of competitive priority. In order to solve the issue of transforming information into an economic resource and its effective circulation on the market, which also involves limiting access to information to ensure the possibility of obtaining a profit from its connection to the civil circuit, the private law (Malaurie at all, 2009 p.411-412 Pop, 2013, p.222 ) and constitutional (Tanase et all, 2017, p.145-146) doctrine and jurisprudence were created many legal regimes for its circulation, such as: trade secret, state secret, copyright, special rights of database holders and others. Information consists of a representation of reality, but also of reflection and projection - which are typical operations of the human intellect - through a well-defined and structured set of symbols - usually accessible to human senses and reason, but also to some of the devices, such as those of automatic calculation.

Given that intellectual property refers to creations of the mind, such as inventions, literary works, works of art, symbols, names, images and designs used in commerce (WIPO), we must recognize that intellectual property rights reward creativity and encourage innovation, including the discovery of new drugs. If intellectual property rights are not protected, creators will be unmotivated, and society will not move forward and consumers will have a limited variety of products.

Meritorious is the opinion after which it is concluded that the works in the industrial field in which human creations are incorporated can be considered works (Lazar, 2002, p.2). However, it is mentioned that the role of aesthetics in the industrial field has increased so much that inventions, brands, designs and industrial models are inextricably linked to quality of life, an important element of consumer orientation and increasing the commercial value of a product; representing, therefore, works of intellectual creation, they (invention, trademark or geographical indication, industrial design) have, along with other works created by people, a vocation for legal protection. However, the separation of intellectual property rights in different categories is done only 
based on their regulations through various normative acts (Лазарев, 1994, p.139).

Thus, the development of science and technology, the increase of industrial indices create unprecedented possibilities for the production of various goods and services used by contemporary consumers, but, with it, there is a reduction of natural resources, large-scale intoxication of the environment and these appeared objective limiters must be considered. Therefore, in any social relationship, there is a certain proportion of free human development and a certain proportion of restrictions. If these two reach the essential interests of the personality and the state, then the concrete social relationship falls within the sphere of legal regulation, acquiring legal character. The first (freedom) turns into a subjective right, and the second (restriction) - into an obligation, interdiction, or legal restriction (Лазарев, 1994, p.139).

Because the use of intellectual creations is likely to win customers and help consumers choose products, services, Paul Roubier, in 1935, called this right, the right of customers (Chavanne \& Brust, 1993, p.467). It is on the border between personal and real rights, which form the third category of rights. Trademark rights differ from personal rights because they are opposable to all. The holder of the right to intellectual creation may oppose all competitors who use the same objects of intellectual property. This is a property right over the results of the intellectual activity that can be opposed "erga omnes" (Domenti, 2016).

In this context, the question remains whether personal data or personal information constitute a commodity or economic potential, which may be subject to alienation or is a non-commercial object, without circulation in civil relations, with a special legal regime, connected to rights and freedoms. fundamental principles of man. Given that the nature of the Internet service cannot have frontier boundaries, and the business models of Internet services provided by US companies that export these services are based on the use of user information, including personal data, they already have become a commodity, being subject to the rules of information circulation. 


\section{Notions about the legal regime of information and personal information in terms of intellectual property}

Information is neither content, nor agent, nor property, nor instruction, nor process, nor method, but information is an independent category, having an abstract and subtle existence - that is, immaterial - that is reflected by states, signals and so on and is an essential element in the process of knowledge. But not all knowledge has the character of information, only those that have a certain value for someone in the process of professional or personal activity. For example, a certain amount for the credit bureaus, which processes the credit history of the customers, presents the information that the data subject has fully paid the installments for the good purchased on credit. Information of a certain value to producers, service providers, and contractors is collected from various sources of information-by-information brokers, is processed according to preestablished criteria, and forms detailed profiles of people (potential consumers), presenting access to this data to concerned people. The activity of the information brokers is based on the agreement of the targeted subject, externalized within several contractual relations with certain targeted subjects - internet services.

Some types of information, even if people are willing to pay the cost, are excluded from the civil circuit, under the pretext of legal-public order and form a state or service secret, trade secret or information that reveals secrets of private life.

According to art. 3 of the Law of the Republic of Moldova on copyright and related rights no. 139 of 02.07.2010,,database - is a compilation of data or other materials, regardless of whether or not they are protected by copyright or related rights, both in mechanizable and in another form, arranged systematically or methodically and accessible by electronic or other means". This legal notion is close, according to its regime, to the generic notion of "data" as information generated by various technical mechanisms or factual data, entered in the computer's memory.

While the information, viewed in the direct sense of the word, is a result of the analysis of factual data with the obtaining from them of a certain meaning and importance forms another data regime (processed or cooked data). We 
consider that art.40 of Law no.139 refers specifically to this category of "processed data", since "The producer of a database that proves that he has made a substantial investment from a qualitative and / or quantitative point of view in obtaining, verifying or presenting its content".

The processing of raw data can be manifested, in the opinion of the Moldovan legislator, by selecting, verifying, classifying and presenting the data, i.e. by interposing the factor of their analysis by the human intellect. In the sense of art. 3 of the Law on the protection of personal data no. 133 of 08.07.2011 - personal data represents any information regarding an identified or identifiable natural person (subject of personal data). In other words, these, in conjunction with the provisions of Law no. 139, form a regime of raw data, not subject to intellectual analysis.

According to art.8 of the Law on access to information no.982 of 11.05.2000, "Personal information is part of the category of official information with limited accessibility and consists of data relating to an identified or identifiable natural person, whose disclosure would constitute a violation of private, intimate and family life". The exercise of the right of access to information may be subject only to the restrictions regulated by organic law and which correspond to the needs:

a) respect for the rights and reputation of another person;

b) respect for the rights and reputation of another personprotection of national security, public order, health protection or protection of society's morals.

The overwhelming mass of raw information, which is important for big data analytics, has no intellectual content and is exclusively informational, such as sensor indicator data, log file servers or subscriber connection information.

However, it can be accepted that the content of users in the form of messages on forums or social networks may contain a certain intellectual product and, in this sense, may become subject to copyright with a certain licensing regime for their users, being an exception, rather than the general rule of the content of the information in the virtual space.

The information community is closely linked to the realization of the principle of freedom of contract (Saveliev, 2016, p.482), which in the field of information technologies is achieved as part of the freedom of identification by 
the contracting parties of the objects of sui generis civil contracts, and their use of the appropriate legal civil circuit mechanism. patrimonial, personal, corporate, exclusive rights.

It is well known that the operation of free internet services, such as search systems, e-mail, social networks, information services is the possibility of using the data of users of these services. Many of them are personal data. Once connected to the Internet, the Internet user inevitably leaves behind personal data, such as name, surname, address, type of information sought, email address, computer name or domain name to which he belongs. Through cookies, created automatically, any internet access results in a collection of personal data.

Considering the technical realities of the functioning of the "Internet", each action of its users can leave a certain mark in the form of a numerical code (digital finger print), which allows, in the end, its identification. The use of the corresponding service can only be done by accepting the click-wrap or browsewrap agreement. The text of these specified agreements allows providers to use users' personal information and the content they display using this information serviceFrom the point of view of the legislation in force, this condition, even incorporated in a standard agreement, forms the consent of the subject of personal data, ie any manifestation of free will, express and unconditional, in written or electronic form, according to the requirements of the document electronic, by which the subject of personal data accepts to be processed the data concerning him, so it represents a unilateral manifestation of will and is subject to the rules of validity of the special normative act, and not of the civil legislation, regarding consent, established in art. 312 of the Civil Code of the Republic of Moldova "Consent is the manifestation, externalized, of the will of the person to conclude a legal act".

Pursuant to the Law on electronic commerce no. 284 of 22.07.2004 "The offer is an electronic document by which a person proposes the conclusion of a contract and sends to other persons the text of the contract containing the contractual clauses, including the mandatory ones provided by this law". The mentioned law does not offer the notion of "electronic document", but by the logical research method we deduce that the legal meaning of the electronic document resides in an electronic information, which has no electronic 
communication status, having as legal purpose the establishment, modification or termination of civil rights and obligations. In other words, the consent of the subject of personal data in electronic form, by which he agrees to process the data concerning him, is an acceptance by which the acceptor agrees to conclude the contract in compliance with the conditions proposed in the offer. The acceptance conditions are supplemented by art. 18 paragraph (4) of Law 284 with the phrase that "Acceptance will contain the text of the contract, proposed by the bidder, without modifying its clauses. If the tenderer is sent the acceptance with the modified terms of the contract, such acceptance shall be considered as a new tender".

The mere sending of the confirmation of the receipt of the offer or the non-sending, or the non-receipt of the acceptance cannot be considered an acceptance within the meaning of this law and in the regime of the contracts concluded in electronic form.

The person's agreement on the use of personal data is no longer a simple consent, but can be appreciated as offering a property interest to his contractor - provider. In reality, innovative business models, in line with the principle of freedom of contract, have considerably weakened the legal categories in the related branches - the notions of non-patrimonial personal rights and human rights. Information technologies have transformed the person's right to privacy and the secrecy of correspondence into objects of sale in the economic sense, and civil law can no longer oppose this process, only by not recognizing this fact and legally maintaining the incessant nature of personal data. The nonrecognition of personal data as an object of the civil circuit cannot solve the problem of fraudulent data processing. To counteract this phenomenon, it is necessary to access the legal-criminal and procedural-criminal mechanisms at the stage of concluding the contract. It is plausible that the Republic of Moldova has ratified the Council of Europe Convention on Cybercrime, adopted in Budapest on 23 November 2001 (Law nr.6-XVI of 02.02.2009 RM). The Law on Preventing and Combating Cybercrime (Law RM nr.20-XVI din 03.02.2009), which regulates the legal relations on preventing and combating cybercrime, was elaborated and adopted; protection and assistance to service providers and users of computer systems; collaboration of public administration authorities with non-governmental organizations and other representatives of 
civil society in the activity of preventing and combating cybercrime; cooperation with other states, with international and regional bodies.

It does not constitute a violation of the rights provided by the Romanian Civil Code, which are permitted by law or by international human rights conventions and pacts, to which Romania is a party.

The exercise of constitutional rights and freedoms in good faith and in compliance with the international pacts and conventions to which Romania is a party does not constitute a violation of the rights provided in this section.

If we assume, for a moment, that personal data do not represent a patrimonial value, i.e. they do not have a price in the coordinate system of civil law, this fact determines their qualification as personal rights, which does not fully characterize the essence of the perspective of the civil circuit and legal protection. But how do we deal with personal data, as well as other information, related to the person, such as geolocation data, internet user content, which are already part of information technologies and are launched in the civil circuit as objects of the civil circuit? In this legal capacity of objects, invested with the capacity to change the right holders in the circuit, we must recognize not the objects of legal relations, as a functionally materialized substance, but subjective civil rights, including over intangible objects, such as exclusive rights, personal, corporate.

The full recognition of personal data as objects of civil rights also implies some restrictions, related to their civil circuit. Taking into account the existing legal regime of personal data, established by the international conventions to which Romania and the Republic of Moldova have acceded, the activity of information brokers and contracts, which they conclude with users, will be further regulated. In addition, the protection of personal data must be done with the help of technical means, namely, encryption technologies, protection mechanisms, incorporated in the design of the service (Privacy by Design), the use of special protocols (Platform for privacy preferences). In the field of personal data, European legislation also identifies "sensitive data", which, by their nature and the high risk of infringement of the fundamental rights and freedoms of individuals, cannot be processed without the possibility of collection, registration, disclosure or transfer. Preserving the area of informational privacy is a guarantee of freedom of thought, action and full 
manifestation of personality (Jugastru, 2017, p10). Special data indicated in Regulation 2016/679 and Directive 95/46 / EC of the European Parliament and of the Council of 24 October 1995 on the protection of individuals with regard to the processing of personal data and on the free movement of such data " (Directive 95/46 / EC, 1995) are genetic data, biometric data, which lead to the unique identification of the person, and data on sexual orientation, data related to the intimacy of the physical, emotional and social personality. It must be acknowledged that there are personal data that affect little or no privacy of the person, i.e.do not lead to the unique identification of the person, and their use by third parties, in a certain security regime for the recipient of such data, would it brings only economic and other benefits and advantages to it.

We must start from the presumption that in situations where this is an important aspect of private life, the knowledge of which by the public is not based on a legitimate public interest, the parties request it, and the judges ensure that the decision is anonymized. But if important aspects of privacy are not discussed, can we talk about a reasonable expectation of respecting this right by anonymizing the decision? The Court noted that, in certain circumstances, restrictions on the reproduction of information that has already entered the public domain may be justified, for example, to prevent the continued dissemination of details of the privacy of a person who is not the subject of any public or political debate. on a matter of general importance. The analysis of this statement could not lead to the conclusion of the violation of the right to privacy by publishing the names in court decisions. The publication of names in court decisions could lead to a violation of the right to privacy if the press or members of the public distort or misrepresent this information. However, in the event of such a case, the tortious civil liability action of the injured party against a newspaper that published information related to his private life, information taken from court decisions published on the Internet, without a public or political debate on a matter of general importance, could have a chance of success.

We must be aware that the protection of personal data is not an exclusive issue of law, and to the extent that this segment of protection is legal, then it can not be solved by imposing artificial barriers in their recognition as objects 
of the civil circuit. such that personal rights, including personal data, are not transferable.

A provision of art.313 of the draft amendment and completion of the Civil Code of the Republic of Moldova: Under the law, any natural person has the right to life, health, physical and mental integrity, free speech, name, honor, professional dignity and reputation, self-image, respect for intimate, family and private life, protection of personal data, respect for his memory and body after death, as well as other such rights recognized by law. These rights are imperceptible and inalienable.

Although governed by various national laws, intellectual property rights (IPR) are also covered by European Union law. Article 118 TFEU provides that, in the context of the establishment and functioning of the internal market, Parliament and the Council, acting in accordance with the ordinary legislative procedure, shall establish measures for the creation of EU intellectual property law to ensure uniform IPR protection in the EU for the establishment of centralized authorization, coordination and control systems at EU level. The European Union's legislative work in this area consists mainly in harmonizing specific aspects of IPR, by creating a single European system, as is the case for the EU trade mark and designs, and will be the case for patents. The European Union Intellectual Property Office (EUIPO) is responsible for managing the EU trademark and EU designs (Intellectual, industrial and commercial property ).

From the point of view of computer programs and databases, Directive 91/250 / EEC requires Member States to protect computer programs through copyright, similar to literary works, within the meaning of the Berne Convention for the Protection of Literary and Artistic Works. It has been codified by Directive 2009/24 / EC of the European Parliament and of the Council. Directive 96/9 / EC provides for the legal protection of databases, defined as "a collection of works, data or other independent elements, arranged systematically or methodically and individually accessible by electronic or other means". The Directive provides for the protection of databases both through copyright, for intellectual creation and through a sui generis right to protect investments (financial, in human resources, effort and energy) in 
obtaining, verifying or presenting the content of databases (Intellectual, industrial and commercial property).

According to the Assessment of the current Copyright Law of the Republic of Moldova, and the draft amendments for harmonisation with EU legislation and International Treaties, it is necessary to restore the tables of concordance for all European directives that will be transposed into national law, being recommended the regulation:

- of some essential notions for copyright and related rights, such as the assignment contract and the command contract;

- of the exclusive right of rebroadcasting, in accordance with the Rome Convention (Articles $3 \mathrm{~g}$ ), 7 and 13). Rebroadcasting means the simultaneous broadcasting by one broadcasting organization of the broadcast of another broadcasting organization;

- of audiovisual performances in accordance with the provisions of the Beijing Treaty on Audiovisual Interpretations and Performances, which entered into force on 28 April 2020. The authorities of the Republic of Moldova must analyze the possibility of transposing Article 17 of Directive (EU) 2019/790, thus deleting Article 66. Infringement of copyright and related rights through computer networks in Law 139/2010. In this respect, it should be taken into account the clarifications in Recitals 64 and 65 of Directive (EU) 2019/790, on the separate application of the provisions of Directive 2000/31/EC on certain legal aspects of information society services, in particular electronic commerce, in the Internal Market, as well as the provisions of EU Directive 2019/790.

\section{Recent jurisprudence of the CJEU in the field of intellectual property versus personal information.}

The CJEU confirmed in 2012 in SAS case C-406/10 that, under Directive 91/250 / EEC, only the expression of a computer program is protected by copyright, the ideas and principles underlying it. Logically, algorithms and programming languages are not protected under this Directive (paragraph 32 of the judgment). The Court emphasized that neither the functionality of a computer program nor the programming language and format of the data files used in a computer program for the operation of certain functions thereof 
constitute a form of expression of that program within the meaning of Article 1 (2) of Directive 91/250 (paragraph 39).

In its judgment in Case C-160/15 (GS Media BV / Sanoma Media Netherlands BV), the CJEU stated that posting a hyperlink on a website to copyrighted works published without the author's consent on another website does not constitute "Communication to the public" if the person who posted that link does not pursue financial gain and acts without knowing that those works were published illegally.

In its judgment in Case C-484/14 of 15 September 2016, the CJEU considered that making a WI-FI network available to the general public free of charge in order to draw the attention of potential customers to the goods and services of a store is a 'service of information society "within the meaning of Directive 2000/31 / EC and confirms that, under certain conditions, a service provider providing access to a communication network may not be held liable. Therefore, copyright holders are not entitled to claim compensation on the grounds that the network has been used by third parties to infringe their rights. Securing the internet connection through a password ensures a balance between the intellectual property rights of the holders, on the one hand, and the freedom to conduct a business of access providers and the freedom to inform network users, on the other hand.

\section{Conclusions}

In conclusion, with the exception of a few legislative limits which have been expressly declared mandatory, there are no specific guidelines for determining whether the limits are mandatory or not. In general, it can be said that the limits to copyright are the expression of the express recognition by the legislature of the interests of users in making certain uses of works protected by copyright without having previously received obtained authorization from the right holder. To promote free competition, the standards of public order in particular impose certain restrictions on the contract in order to prevent the use of contracts to erect an economic power and abuse. As part of our research, our emphasis has been placed on national framework and EU jurispeudence, which respectively could be merged for a good practice for Republic of Moldova, as a country in transition to EU values. 
By "alienation of personal right" we mean the permission of the holder of this right to use the social conditions of their social identity by others, according to their own vision and interest, but limited, to some extent, by the will of the holder of personal right. Permission to use the identification marks of the holder of the personal right may bring certain advantages, including patrimonial, to the person who uses them, therefore the latter may be obliged to pay a remuneration. In this sense, the realization of any subjective right is to be carried out with respect for the rights and legitimate interests of others, as well as the public interest. Namely, the possibility of harming the rights and legitimate interests of others, as well as the public interest, must be seen as a legal barrier to sanctioning legal acts with personal rights, and not the criterion of the inseparability of certain values from the author.

In order to complete the personal data circuit, we will have to talk about concluding unnamed contracts, which will have as object an unnamed legal category of civil rights - information. As we know, concluding unnamed and complex contracts is one of the opportunities to achieve the principle of freedom of contract. The application by analogy to unnamed contracts for the transmission of information of the rules governing similar types of contracts is possible only in compliance with strict legal conditions.

In the EU legal system, the tension between intellectual property law and contract law is more complex, as in Europe the regulation of contractual intellectual property practices is not uncommon, even if freedom of contract is the general rule, while contractual restriction is the exception (Guibault, 1998). In the EU, the relationship between intellectual property exemptions and use contracts is still quite ambiguous, with a growing market inclination to create private intellectual property protection under contract. Thus, in addition to the mandatory provisions of the Computer Program Directives 91/250/EEC and in databases 96/9/EC, the same IP law suggests "a small guideline for determining the validity of a contract restricts the legal exercise of a copyright limitation" (Guibault, 2004).

Acknowledgement: This paper is elaborated in the framework of the Jean Monnet Support to Associations in European Integration and Intellectual Property Protection Studies / EUPROIN, nr. ref. 611344-EPP-1-2019-1-MD-EPPJMO-SUPPA, implemented with financial support of the Erasmus + programme of the European 
Union. "The European Commission's support for the production of this publication does not constitute an endorsement of the contents, which reflect the views only of the authors, and the Commission cannot be held responsible for any use which may be made of the information contained therein"

\section{References}

Chavanne, A., Brust, J.J. (1993). Droit de la propriété industrielle. 4e édition, Paris: Dalloz, p.467

Directive 95/46 /EC of the European Parliament and of the Council of 24 October 1995 on the protection of individuals with regard to the processing of personal data and on the free movement of such data. Official Journal L 281 , 23/11/1995 P. 0031 - 0050. Retrieved from: https://eur-lex.europa.eu/legal-

content/EN/TXT/PDF/?uri=CELEX:31995L0046\&from=EN

Domenti, M. (2016). Particularităţile raportului juridic privind rezultatele creaţiei intelectuale şi evoluţia acestuia, Teză de doctor în drept, Chişinău Guibault, L. (1998). Pre-emption Issues in the Digital Environment: Can Copyright Limitations be Overriden by Contractual Agreements under European Law,

Lelystad: Vermande.

Guibault, L. (2002). Copyright Limitations and Contracts, $\mathrm{PhD}$ thesis.

Jugastru, C. (2017). Reforma europeană în materia datelor cu caracter personal, Regulamentul UE 2016/679 (II), în Revista de drept privat, ${ }^{\circ} 3$, p.10

Lazăr, V. (2002), Infracţiuni contra drepturilor de proprietate intelectuală, Lumina Lex, București. p.2

Лазарев, В.В. (1994). Общая теория права и государства, Москва: Издательство „Юридическая литература”, , p.139

Legea Republicii Moldova privind prevenirea şi combaterea criminalităţii informatice, nr.20-XVI din 03.02.2009, în Monitorul Oficial al Republicii Moldova, 2010, $\mathrm{n}^{\circ} 11-12$, art. 17

Legea Republicii Moldova pentru ratificarea Convenţiei Consiliului Europei privind criminalitatea informatică nr.6-XVI din 02.02.2009, în Monitorul Oficial al Republicii Moldova, 2009, n 37-40, art. 104

Lucan Arjoca, I., (2021). Assessment Report. Assessment of the current Copyright Law of the Republic of Moldova, and the draft amendments 
for harmonisation with EU legislation and International Treaties, February, 2021

Malaurie, Ph., Aynes, L., Yves-Gautier, P. (2009). Drept civil: Contracte speciale. Trad. Diana Dănișor, Wolters Kluwer, București, p.411-412

Pop, L. (2013). Tratat de drept civil. Obligațiile. Vol.II, Regimul juridic general, Universul Juridic, București, p.222

Saveliev, A.I. (2016). Направление эволюции свободы договора под влиянием современных информационных технологий, Свобода договора: Сборник статей, Moscva, p.482

Tănase, A. Secrieru, R., Rusu, L., Strulea, M., Vîlcu-Bajurean, N. (2017). Wolters Kluwer, Comentarii asupra hotărârii Curții Constituţionale a Republicii Moldova nr.19 din 22.06.2015 privind interpretarea articolului 34 alin.(3) din Constituția Republicii Moldova.//Compendiu al jurisprudenței Curții Constituționale a Republicii Moldova: (1995-2017), București, p.145-146 